The following document is a pre-print version of:

Fresia B, Ross P-S, Goaguen E, Bourke A (2017) Lithological discrimination based on statistical analysis of multi-sensor drill core logging data in the Matagami VMS district, Quebec, Canada. Ore Geology Reviews 80:552563

\title{
Lithological discrimination based on statistical analysis of multi- sensor drill core logging data in the Matagami VMS district, Quebec, Canada
}

Bastien Fresia ${ }^{1,2}$, Pierre-Simon Ross ${ }^{1, *}$, Erwan Gloaguen ${ }^{1}$, Alexandre Bourke $^{1}$

1. Institut national de la recherche scientifique, centre Eau Terre Environnement, 490 rue de la Couronne, Québec (QC), G1K 9A9, Canada

2. Now at: Perkoa Zinc Mine, Nantou Minning-BFSA, a Glencore company, Province de Sanguié, Burkina Faso

* Corresponding author, rossps@ete.inrs.ca

\begin{abstract}
In mineral exploration, traditional core logging is largely based on the visual inspection of drilled cores, a process which is often subjective and non-reproducible. However, a number of physical, chemical and mineralogical properties of rocks can now be measured at high spatial resolution on drill cores. The resulting large multiparameter databases can help geologists to quantitatively discriminate between lithologies, study hydrothermal alteration, and potentially vector towards mineralization. Multivariate statistical methods are important tools to assist geologists in interpreting such large databases. We present an application of model-based cluster analysis in the Matagami base metal mining district, more specifically to improve lithological discrimination at the zinc-rich Bracemac and McLeod volcanogenic massive sulfide (VMS) deposits. The model-based cluster analysis method is able to efficiently discriminate different geological units encountered, even in cases where two units are visually similar or in the presence of strong hydrothermal alteration.
\end{abstract}

Keywords: multivariate data; cluster analysis; base metals

\section{Introduction}

Advanced mineral exploration programs are often characterized by extensive diamond drilling operations, resulting in vast repositories of rock core. Conventional core logging is based largely on visual descriptions by geologists, making the core logs subjective and often poorly reproducible. This can cause problems with geological interpretations and block models of the mineralization, and as a result a paradigm shift is required. The goal is not to replace the visual core log by geologists, but to make such logs less subjective and variable (e.g., Gazley et al., 2014) by adding other sources of information to the visual observations.

Quantitative data are commonly acquired and used in the oil and gas industry in all the phases of the development of a reservoir, but this is not yet the case in metal mining and exploration. What is ideally needed in mineral exploration is a complete set of mineralogical, geochemical and physical property information, either using wireline logging (e.g., Keys, 1979), or by working on drill cores when available, or on pulps. Applications include discriminating between different lithologies along the core even if they are visually similar, or characterization of hydrothermal alteration or mineralization. If many drill holes were logged with high-resolution multiparameter measurements, such data could be used to improve the understanding and modeling of the lithology and alteration in 3D. The measurements would also serve as hard data constraints in geophysical inversions (e.g., Tavakoli et al., 2012). Significant progress has been made in this direction using portable instruments such as magnetic susceptibility meters, visible and nearinfrared spectrometers, and portable X-ray fluorescence (pXRF) analyzers (e.g., Herrmann et al., 2001; Gazley et al., 2011; Yang et al., 2011; Durance et al., 2014; Fisher et al., 2014; Gazley and Fisher, 2014; Le Vaillant et al., 2014). Portable instruments can readily 
be taken to core storage sites, or even to the drill rig, to obtain information in a time-sensitive manner. Larger laboratories can also be utilized to study cores, either by bringing the core to the lab or the reverse. One well established example is the Hylogger from Australia, which quickly scans the core for alteration mineralogy (e.g., Tappert et al., 2011). INRS has been operating a trailer-hosted laboratory called LAMROC since 2010; this allows measurements of physical, mineralogical and geochemical properties at high spatialresolution (dm-scale), along with acquisition of line-scan images (Ross et al., 2013, 2014a, 2014b; Bourke and Ross, 2015). LAMROC measures two physical parameters (density, magnetic susceptibility), about 20 geochemical parameters using two pXRF analyzers, and alteration mineralogy using near-infrared spectrometry. Most of these instruments and sensors are integrated in a computer-controlled multi-sensor core logger (more methodological information is provided below). In this study we apply multivariate statistical analysis to take full advantage of the LAMROC data.

Multivariate statistics have been shown in sedimentology and hydrocarbon exploration to objectively classify the data into lithological units or lithofacies (e.g., Rice et al., 1976; Delfiner et al., 1987; Bosch et al., 2002; Reátegui et al., 2005; Kaźmierczuk and Jarzyna, 2006; Tang and White, 2008; Rowe et al., 2012). Since the early 1960 s, several multivariate statistical techniques have been developed for automatic segmentation of log data (e.g., Testerman, 1962; Gill, 1970; Hawkins, 1972; Hawkins and Ten Krooden, 1979). The main hypothesis is that measurements of specific physico-chemical properties on cores allows for the fullcharacterization of the lithology while automating, at least in part, its characterization (Kileen et al., 1997; Maerz and Zhou, 1999; Bosch et al., 2002; Hill et al., 2015).

The aim of this paper is to start to develop a multivariate statistical workflow applicable to igneous rocks and mineral exploration. We focus on the Bracemac-McLeod sector in the Matagami base metal mining district within the Abitibi Subprovince, Quebec, Canada. We concentrate on downhole lithological discrimination using the parameters measured by LAMROC and apply cluster analysis to differentiate protoliths along the drill cores.

\section{Geological context}

The Matagami mining district is located in the northern part of the Archean Abitibi Subprovince in Quebec (Figs. 1a, 1b). Matagami constitutes an important zinc district with more than $60 \mathrm{Mt}$ of zincrich ore (19 deposits and prospects, including 13 past and current producers). All of the known VMS deposits are spatially associated with extensive felsic bands that are divided into the North Flank, the South Flank and the West Camp (Fig. 1c).

The Bracemac-McLeod mine, where this study is located, occurs in the SE corner of the South Flank. The general submarine volcanic stratigraphy of the South Flank, as proposed by Sharpe (1968) and validated by Piché et al. (1993) and Debreil (2014), is divided into the Watson Lake Group at the base and the Wabassee Group at the top (Fig. 2).

The interface between these groups is marked by a tuffaceous unit known as the "Key Tuffite" (Genna et al., 2014, and references therein) which corresponds to the stratigraphic level of the major VMS deposits. The Watson Lake Group is composed of (1) a lower dacite (500 m thick minimum; Piché et al. 1993) and (2) an upper rhyolite ( 1500 m thick; $2725.9 \pm 0.8 \mathrm{Ma}$; Ross et al. 2014c). The Wabassee Group ( 3000 m thick) mostly comprises massive to pillowed lavas of basaltic to andesitic composition (Debreil, 2014). However, at least two felsic units are present in the Wabassee Group along the South Flank (Fig. 2). At the former Perseverance mine, the hanging wall is the Dumagami Dacite (up to $400 \mathrm{~m}$ thick), whereas the Bracemac Rhyolite (up to $70 \mathrm{~m}$ thick) is the immediate hanging wall of the Bracemac and McLeod deposits. The ages of these two rhyolites are $2725.4 \pm 0.7$ and $2725.8 \pm 0.7$ Ma, respectively (Ross et al., 2014c). Both the Watson Lake and the Wabassee groups are locally crosscut by late phases of the underlying Bell River Complex, a large synvolcanic gabbro-anorthosite layered intrusion dated at 2724.6 $\pm 2.5 \mathrm{Ma}$ (Mortensen, 1993). This intrusion is generally interpreted as the thermal engine for the formation of the VMS deposits (Piché et al., 1993; Maier et al., 1996; Carr et al., 2008).

Figures 3 to 5 illustrate the Bracemac and McLeod sectors; the main ore lenses occupy the same stratigraphic level than the Key Tuffite. Other "tuffites" (volcano-exhalative horizons) are also present within the mafic to intermediate lavas. The hangingwall and footwall rhyolites can be quite similar to each other, both visually and chemically. Also, tholeiitic basalts are not always visually distinguishable from transitional andesites and/or mafic to intermediate, fine-grained intrusives in the Wabassee Group, especially if hydrothermal alteration is present. The whole sequence is cut by various intrusions. Intense chlorite-sericite alteration is present below (and sometimes above) the ore lenses.

\section{Multi-sensor core logging}

The dataset acquired in this study was measured using a high-resolution, semi-automated multi-sensor core logger housed in a mobile laboratory called LAMROC. The data acquisition sensors and methods are explained in Ross et al. (2013, 2014a), so only a brief summary is provided here. The drill cores are first 
cleaned and transferred into $1.5 \mathrm{~m}$-long core boats. A geologist decides on the location of each measurement point, typically every 20 to $30 \mathrm{~cm}$ down core, ensuring that the selected spots are representative. In the multisensor core logger (designed, manufactured and installed by Geotek Ltd of Daventry, England), the core sections are moved along a track by a computercontrolled pusher. The core stops within, or below, each sensor and instrument, for the required time to make measurements. Volumetric magnetic susceptibility is determined using a loop-style MS2C Core Logging Sensor from Bartington Instruments Ltd. (Oxford, England). Rock density is based on attenuation of gamma rays passing through the core, using a gamma source and detector supplied by Geotek. Visible light and near-infrared spectrometry relies on a LabSpec 2600 visible/near-infrared spectrometer from Analytical Spectral Devices (ASD) Inc. (Boulder, Colorado), which measures reflections between 350 and $2500 \mathrm{~nm}$. Spectral resolution is $3 \mathrm{~nm}$ at a wavelength of $700 \mathrm{~nm}, 6 \mathrm{~nm}$ at $1400 \mathrm{~nm}$ and $6 \mathrm{~nm}$ at $2100 \mathrm{~nm}$. Automated mineralogical identification is done using the software "The Spectral Geologist" (TSG), Core version, commercialized by AusSpec International of Australia and New Zealand. Two Delta Premium pXRF analyzers from Olympus Innov-X (Woburn, Massachusetts) analyzers are used separately from the logger to save time. These analyzers have $40 \mathrm{kV}, 4 \mathrm{~W}, \mathrm{Rh} \mathrm{X}$-ray tubes and large area silicon drift detectors. For the dataset presented here, the analyzers were both set to 'mining plus' mode and the integration time was $60 \mathrm{~s}$ per spot, i.e. $30 \mathrm{~s}$ per beam. The data from the two analyzers were leveled to compensate from inter-analyzer differences. The geochemical elements which are considered usable within this data set are $\mathrm{Al}, \mathrm{Ca}, \mathrm{Cu}, \mathrm{Fe}, \mathrm{K}, \mathrm{Mg}, \mathrm{Mn}, \mathrm{Si}, \mathrm{Ti}, \mathrm{Zn}$ and $\mathrm{Zr}$. Site- and analyzer-specific corrections factors were determined for $\mathrm{Al}, \mathrm{Fe}, \mathrm{Mn}, \mathrm{Si}, \mathrm{Ti}$ and $\mathrm{Zr}$ using traditional laboratory analyses for a range of lithologies from mafic to felsic. Ten diamond drill holes have been logged at Matagami with the multi-sensor core logger (Ross et al., 2011, 2012, 2013, 2014b) but here we focus on two NQ holes from the Bracemac-McLeod area. The dataset for those two drillholes represents 3269 data points of density, magnetic susceptibility and geochemistry spread over 1761 meters of core. Drillhole MC-05-18 crosses the McLeod VMS deposit and the typical host lithologies there (Fig. 4). Drillhole BRC-08-72 crosses the Bracemac VMS deposit, which comprises three ore lenses, and the main lithologies and hydrothermal alteration zones (Fig. 5).

\section{Qualitative data analysis}

The main hypothesis we are testing is as follows: the measured parameters allow characterization of the lithology and alteration. Figures 6 to 8 illustrate multi- parameter data for drill hole MC-05-18. Equivalent plots for drill hole BRC-08-72 are available in Fresia (2013) and Ross et al. (2013).

Physical properties on their own give some lithological clues. For instance, felsic rocks are typically less dense than mafic ones; many gabbros have high magnetic susceptibilities; etc. (Fig. 6). However, intrinsic variability within lithologies and the effects of hydrothermal alteration mean that the physical properties of different rock types can partly overlap (Fig. 9). For example, the two rhyolites, Watson Lake and Bracemac, overlap, and some felsic dikes also have similar physical properties to these extrusive rhyolites. However, one specific felsic dike in MC-05-18 (near 300 m, Fig. 6) plots in a distinct field of low density and low magnetic susceptibility (Fig. 9, red squares).

Geochemical measurements are critical to classify lithology. For example, downhole profiles of immobile element ratios such as $\mathrm{Ti} / \mathrm{Zr}$ and $\mathrm{Al} / \mathrm{Zr}$ allow quick identification of lithological contacts (Fig. 6). Major differences, such as between mafic and felsic units, are well identified in this manner but in some cases could not have been described during the visual inspection of the rocks, e.g., between $225 \mathrm{~m}$ and $350 \mathrm{~m}$ in MC-0518 , where variations in ratios of immobile elements suggest the presence of intrusive rocks within the mafic volcanic sequence.

Downhole elemental profiles show variations coming from both lithology and alteration (Fig. 7). In terms of lithology, the typical high $\mathrm{Zr}$ values, and low Ti values, of the Bracemac and Watson Lake rhyolites are obvious. These rhyolites also have higher Si but lower Mn than the mafic lithologies above. Felsic dikes are characterized by very low $\mathrm{Fe}$ and $\mathrm{Mn}$. Chloritic alteration is associated with a decrease of $\mathrm{Si}$ and an increase of $\mathrm{Fe}$ in rhyolites, but this is much more obvious for drill hole BRC-08-72 (see Fig. 14 in Ross et al., 2013).

Near-infrared mineralogy provides information on both lithologies and hydrothermal alteration (Fig. 8). The minerals most associated with hydrothermal alteration are chlorite and fine-grained white micas ("sericite"). Amphiboles, carbonates and epidote belong mainly to intrusive rocks and mafic to intermediate volcanic rocks.

\section{Model-based clustering for lithological discrimination}

To get the best lithological model from the mutiparameter data, all relevant variables should be analyzed together. This can be done visually on downhole profiles combining physical properties with geochemical ratios (Fig. 6), but this approach is timeconsuming and subjective. Multivariate statistical approaches provide robust and quantitative algorithms 
for data classification and statistical modeling. The approach used here is cluster analysis, which permits the interpretation and the recognition of patterns and groups inside large datasets (e.g., Delfiner et al., 1987; Harris et al., 1999; Maerz and Zhou, 1999; Bosch et al., 2002).

\subsection{Methods}

Cluster analysis aims to create subgroups in a dataset by linking or splitting the various samples according to the similarities of their multivariate characteristics, in our case their physico-chemical parameters. No strong assumption is made on linearity and these tools allow for more flexibility and accuracy in defining complex statistical relationships. This classification is typically obtained by the use of calculated similarity criteria, hence avoiding the use of prior assumptions or training datasets to pre-define the characteristics of each group. We use a model-based cluster analysis scheme (Fig. 10), implemented in Matlab, based on the work of Banfield and Raftery (1993) and Fraley and Raftery (2002), and described in Fresia (2013). Compared to more conventional cluster analysis methods, the main difference is a probabilistic approach for the calculation of similarity models of samples - until a statistically relevant number of groups is obtained - rather than a mathematical calculation of similarity criteria.

Classification results greatly depend on the choice of the input variables. Because our goal was to distinguish different protoliths, we selected geochemical variables not strongly influenced by hydrothermal alteration ( $\mathrm{Al}, \mathrm{Ti}$ and $\mathrm{Zr}$, which are immobile elements) as well as the ratio between density and magnetic susceptibility. Experience has shown that this physical property ratio is useful to separate classes of rocks having very similar chemical signatures (Fresia, 2013). A maximum number of classes is specified by the geologist at this stage, based on goals and local geological knowledge. The algorithm will produce statistical models with different numbers of classes up to the maximum number specified, and select the "best" model based on statistical considerations.

The type of classification algorithm implemented is the expectation-maximization (EM) algorithm (Fraley and Raftery, 2002), which maximizes the probability of each measurement point belonging to a specific cluster (or class), creating several models depending on the classification parameters. The best model is chosen using a Bayesian Information Criterion (BIC) (Schwartz, 1978; Raftery, 1995).

\subsection{Application to the Bracemac-McLeod sector}

Figures 11 and 12 show the results of the modelbased clustering as pseudo-logs of the lithologies. The horizontal axis of the right-most column is the confidence that a given data point belongs to one class or the next, expressed from 0 to 1 . If a point belongs $65 \%$ to class 1 and $15 \%$ to class 2 , the bar representing the classes is filled between $0 \%$ and $65 \%$ with the color of the first class and from $65 \%$ to $80 \%$ with the color of the second.

The pseudo-logs (Figs. 11, 12) clearly differentiate the major lithologies encountered in the drillholes, and are little influenced by mineralization and alterationrelated variations in the rocks. Basalts (dark green in the pseudo-log) and andesites (light green) are properly discriminated, even if they were not in the visual core description. The two rhyolites, Watson Lake (yellow) and Bracemac (purple), are well separated by the statistical model, and so are various intrusive rocks.

The pseudo-logs also highlight numerous small intrusions, especially in the more altered zones beneath the mineralization $(212-240 \mathrm{~m}$, and $575-595 \mathrm{~m}$ in BRC08-72; 200-450 $\mathrm{m}$ in MC-05-18). Those intrusions can be quite difficult to differentiate visually from lavas when both lavas and intrusions are fine-grained. The models show good ability to differentiate lavas from intrusions and the different types of intrusions.

One weak point of cluster analysis is that the method does not allow to automatically assign a type of lithology to each class created, as opposed to some "training" statistical methods such as discriminant analysis. Numbered classes are therefore converted to interpreted lithologies based on local geological knowledge and a comparison with detailed geochemical investigations based on whole rock laboratory analyses (Debreil, personal communication, 2013).

There are some limitations to the models in the portions of the drill holes characterized by rapid lithological variations. For example, between 410 and $485 \mathrm{~m}$ in BRC-08-72, the confidence in the model decreases (Fig. 11), due to the strong vertical variations in the $\mathrm{Ti} / \mathrm{Zr}$ ratio and the overlapping multivariate signature of mafic to intermediate volcanic rocks and some gabbros. Another limitation is the grouping of tuffites with intrusions - e.g., 63-68 $\mathrm{m}$ and 78-80 $\mathrm{m}$ in BRC-08-72 (Fig. 11). In these cases, physico-chemical parameters are not sufficient and only visual observations can properly classify tuffites, which contain laminations and other typical textures.

\section{Discussion}

Cluster analysis is an efficient way to facilitate downhole lithological discrimination in two drill holes in the Bracemac-McLeod area of the Matagami mining district, and may be effective elsewhere. At BracemacMcLeod, the statistical model (pseudo-log) successfully identifies the main lithologies. It also separates the Lower Andesite from the Upper Basalt 
(Debreil, 2014), which are two visually identical volcanic units with different geochemical signatures. The model further separates mafic to intermediate intrusions from mafic to intermediate lavas based on physical properties and immobile element ratios. Although thick coarse-grained gabbros and diorites are readily distinguished from lavas based on their texture, thinner finer-grained intrusions can look very much like mafic to intermediate lava flows in drill core. Consequently, finer-grained intrusions were underestimated in the original logs. Finally, the pseudo$\log$ successfully separates the two rhyolites at Bracemac-McLeod, which look very much alike: one of these rhyolites is the footwall to most ore lenses whereas the other is the hangingwall, making the ability to sort them apart critical.

One of the advantages of the model-based clustering algorithm used here is to provide a statistical estimate on the ideal number of lithologies in the dataset according to the raw data repartition (i.e. statistical data structure). Limits of these methods are reached for units with important variations in their intrinsic properties and for the tuffites. For those units, a visual interpretation is required or clustering based not only on a zero distance statistical relation, but also with the texture or spatial cross-covariance models.

The use of additional physico-chemical parameters could improve the results of the cluster analysis if they are carefully chosen and are independent from the alteration. The semi-automation of the algorithm is thus useful as it allows a trial-and-error approach as the process can be repeated until the geologically most plausible results are obtained.

Alternative statistical methods involving training sets such as factor analysis, random forest, or relevance vector machine could also be useful to interpret larger areas and cross-correlations between drill holes and sectors. But those methods require the existence of a large property database for well-defined geological units.

Taking into account the "position" parameter during the calculation of the mathematical distances as proposed by Gowda and Krishna (1978) for example would also be helpful to position geological contacts. There is a higher probability that two neighboring data points belong to the same lithology than two distant points, but this is not taken into account in the current study.

\section{Conclusions}

Large databases of physical and geochemical properties can help discriminate between different lithologies even if visually similar, or if the protoliths are hidden by hydrothermal alteration such as is typical near VMS deposits. This allows a better understanding of the geological setting of mineral deposits and can help mineral exploration. To make full use of the data, multivariate statistic analyses can be utilized.

The model-based cluster analysis method is able to efficiently discriminate different geological units encountered in the present study. The model "decides" on the optimal number of classes based on statistics, without the need for preliminary knowledge (although the geologist must specify a plausible maximum number of classes). The variables to be used in the clustering exercise must be carefully selected as representative of the primary lithology (protolith), and not influenced by hydrothermal alteration. In the Bracemac-McLeod example, the main geological units are correctly identified by the pseudo-log, providing a first-order validation of the model. The pseudo-log however points out certain areas along the drill holes where the lithology appears to be different than that identified in the original company logs based largely on visual observations and widely spaced laboratory geochemistry. Such differences between the original $\log$ and the pseudo-log notably arise in areas of more intense chlorite alteration where the primary textures may be difficult to recognize, and thus exploration geologists do not tend to take many whole rock samples for geochemistry.

The main limits of the implemented model-based cluster analysis are (1) the inability to take the sample position along the drill hole into account when assigning the classes; (2) the impossibility to sort of lithologies that are only dissociable by visual observations, and not by different physico-chemical properties (this will be a limitation of all statistical methods); (3) the inability to deal with large intra-unit variations in physico-chemical parameters (some of these apparent intra-unit variations are based on the measurement methods of the multi-sensor core logger, e.g., pXRF).

Physico-chemical databases and multivariate statistical methods are unlikely to ever replace geologists. The textures and structures seen by geologists are not captured in these databases, as also noted by Gazley et al. (2014). Even in a statistical modeling context, geological experience and judgment are needed to select relevant variables or number of classes for the models and interpret the results. In this study we produced a large number of cluster models for the studied drill holes, changing the parameters and maximum class numbers by trial-and-error. Only what we see as the best models, from a geological point of view, were presented. The results of statistical analyses remain models that ought to be validated using various approaches, observations and data as well as by the skills and the knowledge of the geologist. 


\section{Acknowledgments}

Data acquisition in Matagami was funded by a grant from Ministère des Ressources naturelles et de la Faune du Québec and was made possible through the logistical collaboration of Xstrata Zinc Canada (now Glencore). We discussed Matagami geology with Robin Adair, Michel Allard, Patrick Carr, Julie-Anaïs Debreil, Michel Dessureault, Gilles Roy, Patrick Mercier-Langevin and Pierre Pilote, among others. The first author's MSc project at INRS was funded by FRQNT (research grant to PSR). Bernard Giroux and Eric Grunsky made comments on the MSc thesis which helped to clarify some points discussed in this paper. We thank Michael Gazley, Jeff Harris and an anonymous reviewer for their constructive comments on the manuscript.

\section{References}

Adair. R., 2009. Technical report on the ressource calculation for the Bracemac-McLeod discoveries, Matagami project, Quebec. National Instrument 43-101 report prepared on behalf of Donner Metals Ltd. (Vancouver, British Colombia), February 24, 2009, 132 p.

Banfield, J.D., Raftery, A.E., 1993. Model-based Gaussian and non-Gaussian clustering. Biometrics 49, 803-821.

Bosch, M., Zamora, M., Utama, W., 2002. Lithology discrimination from physical rock properties. Geophysics 67, 573-581.

Bourke, A., Ross, P.-S., 2015. Portable X-ray fluorescence measurements on exploration drill cores: comparing performance on unprepared cores and powders for "whole-rock" analysis. Geochemistry: Exploration, Environment, Analysis, DOI 10.1144/geochem2014-326

Carr, P.M., Cathles, L.M., Barrie, C.T., 2008. On the size and spacing of volcanogenic massive sulfide deposits within a district with application to the Matagami District, Quebec. Econ. Geol. 103, 1395-1409.

Debreil, J.-A., 2014. Évolution volcanologique et chimicostratigraphique du district minier de Matagami, Sousprovince de l'Abitibi, Québec. $\mathrm{PhD}$ thesis, Institut national de la recherche scientifique, Quebec City, Canada, 279 pp.

Delfiner, P., Peyret, O., Serra, O., 1987. Automatic determination of lithology from well logs. Society of Petroleum Engineers Formation Evaluation 2, 303-310.

Durance, P., Jowitt, S.M., Bush, K., 2014. An assessment of portable X-ray fluorescence spectroscopy in mineral exploration, Kurnalpi Terrane, Eastern Goldfields Superterrane, Western Australia. Applied Earth Science (Trans. Inst. Min. Metall. B) 123, 150-163.

Fisher, L., Gazley, M.F., Baensch, A., Barnes, S.J., Cleverley, J., Duclaux, G., 2014. Resolution of geochemical and lithostratigraphic complexity: a work flow for application of portable X-ray fluorescence to mineral exploration. Geochemistry: Exploration, Environment, Analysis 14, 149-159.

Fraley, C,. Raftery, A.E., 2002. Model-based clustering, discriminant analysis, and density estimation. Journal of the American Statistical Association 97, 611-631.
Fresia, B., 2013. Analyses multivariées de données de forage de la région de Matagami. MSc thesis, Institut national de la recherche scientifique, Quebec City, Canada, 152 pp.

Gazley, M.F., Fisher, L.A., 2014. A review of the reliability and validity of portable X-ray fluorescence spectrometry (pXRF) data. In: Mineral Resource and Ore Reserve Estimation - The AusIMM Guide to Good Practice. Second edition. The Australasian Institute of Mining and Metallurgy, Melbourne, 69-82.

Gazley, M. F., Vry, J. K., du Plessis, E., Handler, M. R., 2011. Application of hand-held X-ray fluorescence analyses to Metabasalt Stratigraphy, Plutonic Gold Mine, Western Australia. Journal of Geochemical Exploration $110,74-80$.

Gazley, M.F., Tutt, C.M., Fisher, L.A., Latham, A.R., Duclaux, G., Taylor, M.D. et al., 2014. Objective geological logging using portable XRF geochemical multi-element data at Plutonic Gold Mine, Marymia Inlier, Western Australia. J. Geochem. Explor. 143, 7483.

Genna, D., Gaboury, D., Roy, G., 2014. The Key Tuffite, Matagami Camp, Abitibi Greenstone Belt, Canada: petrogenesis and implications for VMS formation and exploration. Mineralium Deposita 49, 489-512.

Gill, D., 1970. Application of a statistical zonation method to reservoir evaluation and digitized-log analysis. American Association of Petroleum Geologists Bulletin 54, 719729.

Gowda, K.C., Krishna, G., 1978. Agglomerative clustering using the concept of mutual nearest neighbourhood. Pattern Recognition 10, 105-112.

Harris, J.R., Wilkinson, L., Grunsky, E., Heather, K., Ayer, J., 1999. Techniques for analysis and visualization of lithogeochemical data with applications to the Swayze greenstone belt, Ontario. Journal of Geochemical Exploration 67, 301-334.

Hawkins, D.M., 1972. On the choice of segments in piecewise approximation. Journal of Institute for Mathematics and its Applications 9, 250-256.

Hawkins, D.M., Ten Krooden J.A., 1979. Zonation of sequences of heteroscedastic multivariate data. Computers \& Geosciences 5, 189-194.

Herrmann, W., Blake, M., Doyle, M., Huston, D., Kamprad, J., Merry, N., et al., 2001. Short wavelength infrared (SWIR) spectral analysis of hydrothermal alteration zones associated with base metal sulfide deposits at Rosebery and Western Tharsis, Tasmania, and Highway-Reward, Queensland. Econ. Geol. 96, 939-955.

Hill, E.J., Robertson, J., Uvarova, Y., 2015. Multiscale hierarchical domaining and compression of drill hole data. Computers \& Geosciences 79, 47-57.

Kaźmierczuk, M., Jarzyna, J., 2006. Improvement of lithology and saturation determined from well logging using statistical methods. Acta Geophysica 54, 378-398.

Keys, W.S., 1979. Borehole geophysics in igneous and metamorphic rocks. In Society of Professional Well Log Analysts Annual Logging Symposium, 20th, Tulsa, Okla, p 1-26.

Maerz, N.H., Zhou, W., 1999. Multivariate analysis of bore hole discontinuity data. Rock Mechanics for Industry, Proceedings of the $37^{\text {th }}$ US Rock Mechanics Symposium, Vail Colorado, p 431-438. 
Maier, W.D., Barnes, S.-J., Pellet, T., 1996. The economic significance of the Bell River Complex, Abitibi subprovince, Quebec. Can. J. Earth. Sci. 33, 967-980.

Mortensen, J.K., 1993. U - Pb geochronology of the eastern Abitibi Subprovince. Part 1: Chibougamau - Matagami Joutel region. Can. J. Earth. Sci. 30, 11-28.

Le Vaillant, M., Barnes, S.J., Fisher, L., Fiorentini, M.L., \& Caruso, S., 2014. Use and calibration of portable X-ray fluorescence analysers: application to lithogeochemical exploration for komatiite-hosted nickel sulphide deposits. Geochemistry: Exploration, Environment Analysis 14, 199-209.

Piché, M., Guha, J., Daigneault, R., 1993. Stratigraphic and structural aspects of the volcanic rocks of the Matagami mining camp, Quebec; implications for the Norita ore deposit. Econ. Geol. 88, 1542-1558.

Raftery, A.E., 1995. Bayesian model selection in social research (with Discussion). Sociological Methodology 25, 111-196.

Reátegui, K., Martínez, M., Esteves, I., Gutiérrez, J.V., Martínez, A., Meléndez, W., Urbani, F. 2005. Geochemistry of the Mirador Formation (Late EoceneEarly Oligocene), southwestern Venezuela: Chemostratigraphic constraints on provenance and the influence of the sea level. Geochemical Journal 39, 213226.

Rice, R.M., Gorsline D.S., Osborne R.H., 1976. Relationships between sand input from rivers and the composition of sands from the beaches of Southern California. Sedimentology 23, 689-703.

Ross, P.-S., Bourke, A., Fresia, B., Debreil, J.A., 2011. Analyse multiparamétrique à haute résolution de carottes de forage dans la région de Matagami - Partie 2, résultats préliminaires. Report submitted to Ministère des Ressources naturelles et de la Faune du Québec, number MB 2011-03, 32 p.

Ross, P.-.S, Bourke, A., Fresia, B., Debreil, J.A., 2012. Analyse multiparamétrique à haute résolution de carottes de forage dans la région de Matagami 2010-2012, Rapport final. Report submitted to Ministère des Ressources naturelles et de la Faune du Québec, number MB 2012-05, $128 \mathrm{p}$

Ross, P.-S., Bourke, A., Fresia, B., 2013. A multi-sensor logger for rock cores: Methodology and preliminary results from the Matagami mining camp, Canada. Ore Geol. Rev. 53, 93-111.

Ross, P.-S., Bourke, A., Fresia, B., 2014a. Improving lithological discrimination in exploration drill-cores using portable X-ray fluorescence measurements: (1) testing three Olympus Innov-X analysers on unprepared cores.
Geochemistry: Exploration, Environment, Analysis 14, 171-185.

Ross, P.-S., Bourke, A., Fresia, B., 2014b. Improving lithological discrimination in exploration drill-cores using portable X-ray fluorescence measurements: (2) applications to the $\mathrm{Zn}-\mathrm{Cu}$ Matagami mining camp, Canada. Geochemistry: Exploration, Environment, Analysis 14, 187-196.

Ross, P.-S., McNicoll, V.J., Debreil, J.A., Carr, P., 2014c. Precise U-Pb geochronology of the Matagami mining camp, Abitibi Greenstone Belt, Quebec: stratigraphic constraints and implications for volcanogenic massive sulfide exploration. Econ. Geol. 109, 89-101.

Rowe, H., Hughes, N., Robinson, K., 2012. The quantification and application of handheld energydispersive $\mathrm{x}$-ray fluorescence (ED-XRF) in mudrock chemostratigraphy and geochemistry. Chemical Geology 324-325, 122-131.

Roy, G., Allard, M., 2006. Matagami, une approche ciblée sur de nouveaux concepts [conference abstract]. Québec Exploration 2006, Ministère des Ressources naturelles et de la Faune, Québec, report DV 2006-03, p. 13.

Schwarz, G., 1978. Estimating the dimension of a model. The Annals of Statistics 5, 461-464.

Sharpe, J.I., 1968. Geology and sulfide deposits of the Matagami area, Abitibi-East County. Ministère des Richesses Naturelles du Québec, report RG-137(A), 130 p.

Tang, H., White, C.D., 2008. Multivariate statistical log logfacies classification on a shallow marine reservoir. Journal of Petroleum Science and Engineering 61, 88-93.

Tappert, M., Rivard, B., Giles, D., Tappert, R., Mauger, A., 2011. Automated drill core logging using visible and near-infrared reflectance spectroscopy: a case study from the Olympic Dam deposit, South Australia. Econ. Geol. 106, 289-296.

Tavakoli, S., Elming, S.-A., Thunehed, H., 2012. Geophysical modelling of the central Skellefte district, Northern Sweden; an integrated model based on the electrical, potential field and petrophysical data. Journal of Applied Geophysics 82, 84-100.

Testerman, J.D., 1962. A statistical reservoir-zonation technique. Journal of Petroleum Technology 14, 889-893.

Yang, K., Huntington, J.F., Gemmell, J.B., Scott, K.M., 2011. Variations in composition and abundance of white mica in the hydrothermal alteration system at Hellyer, Tasmania, as revealed by infrared reflectance spectroscopy. J. Geochem. Explor. 108, 143-156. 


\section{FIGURES}

Figure 1: (a) Location of the Abitibi Subprovince in eastern Canada. (b) Location of the Matagami district in the Abitibi Subprovince. (c) Simplified geological map of the Matagami district and location of past and current producers (modified from Roy and Allard, 2006). Bracemac and McLeod are two VMS deposits that are currently mined together.

Figure 2: Schematic geological succession of the South Flank. Simplified from Debreil (2014). Brc-McL = Bracemac-McLeod sector.

Figure 3: Geological map of the Bracemac - McLeod sector highlighting the position of the two studied drill holes.

Figure 4: Cross-section through the McLeod VMS deposit illustrating the position of drill hole MC-05-18, modified from Adair (2009).

Figure 5: Cross-section through the Bracemac VMS deposit illustrating the position of drill hole BRC-08-72, modified from Adair (2009).

Figure 6: Physical properties and geochemical ratios (pXRF) as a function of depth in MC-05-18. n.d. = no data (massive sulfides missing); I1, I2, I3 = interpreted dykes (felsic, intermediate, mafic). 'Basalt' on figures 6-8 is a logging term that includes all mafic to intermediate volcanic rocks.

Figure 7: Geochemical data (pXRF) as a function of depth in MC-05-18. n.d. = no data (massive sulfides missing).

Figure 8: Near-infrared mineralogy as a function of depth in MC-05-18. In the plot of mineral groups automatically extracted by TSG Core, black lines show the main group whereas superimposed red squares are the subsidiary mineral groups. N.M.D. = no mineral detected.

Figure 9: Magnetic susceptibility versus density for drill hole MC-05-18. A three point moving average has been applied to the data.

Figure 10: Flowchart of the model-based cluster analysis method. BIC = Bayesian Information Criterion.

Figure 11: Results of the cluster analysis compared to the original company log and to parameters used for the analysis, drill hole BRC-08-72. On the right (arrows), some results of geochemical classifications from J.-A. Debreil (personal communication, 2013). The statistical model (pseudo-log) shows the two more probable lithologies from the analysis with their confidence degrees in percent. N.D. = no data. Parameters are represented as raw data of physical parameters and ratios of chemical parameters for clarity. From Fresia (2013).

Figure 12: Results of the cluster analysis compared to the original company log and to parameters used for the analysis, drill hole MC-05-18. N.D. = no data. Parameters are represented as raw data of physical parameters and ratios of chemical parameters for clarity. 

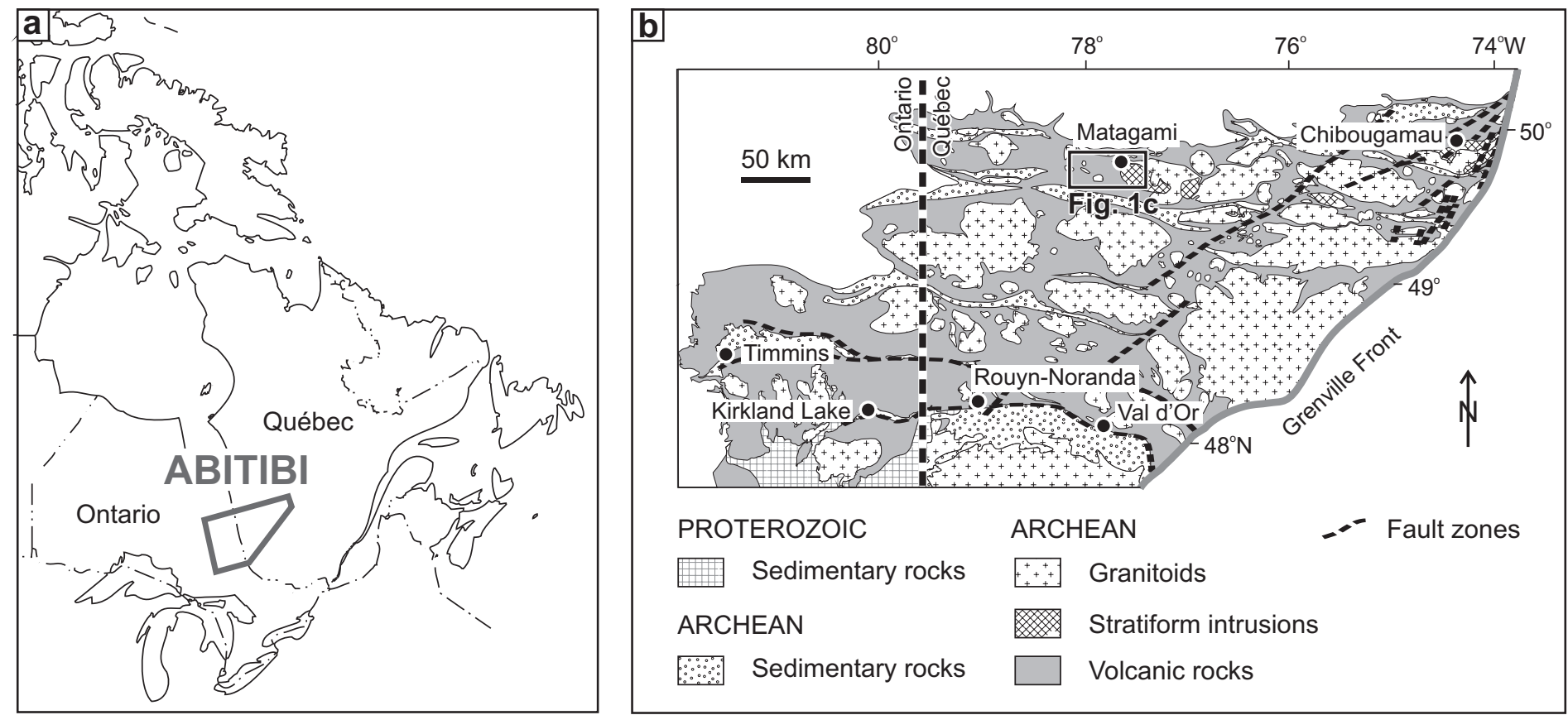

C

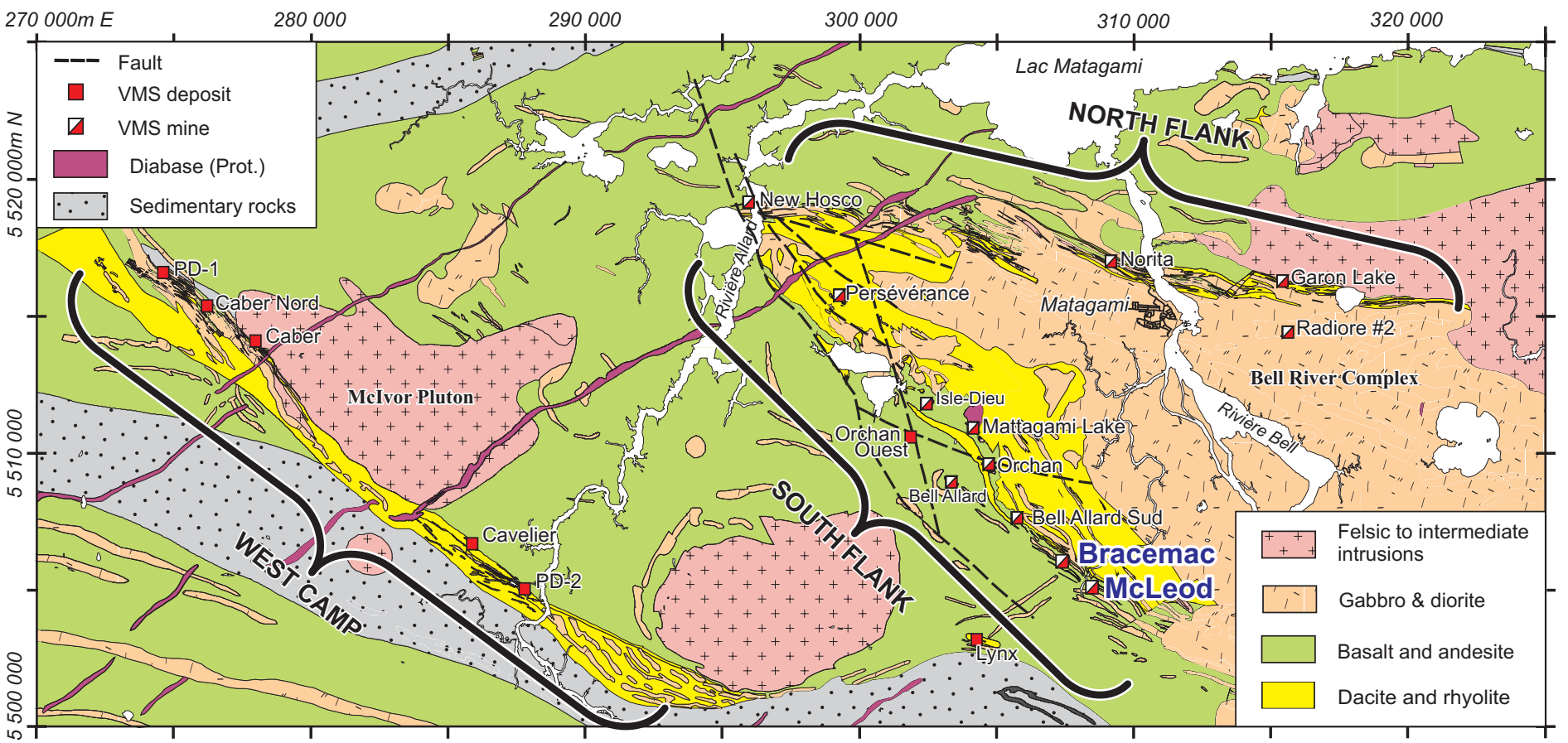




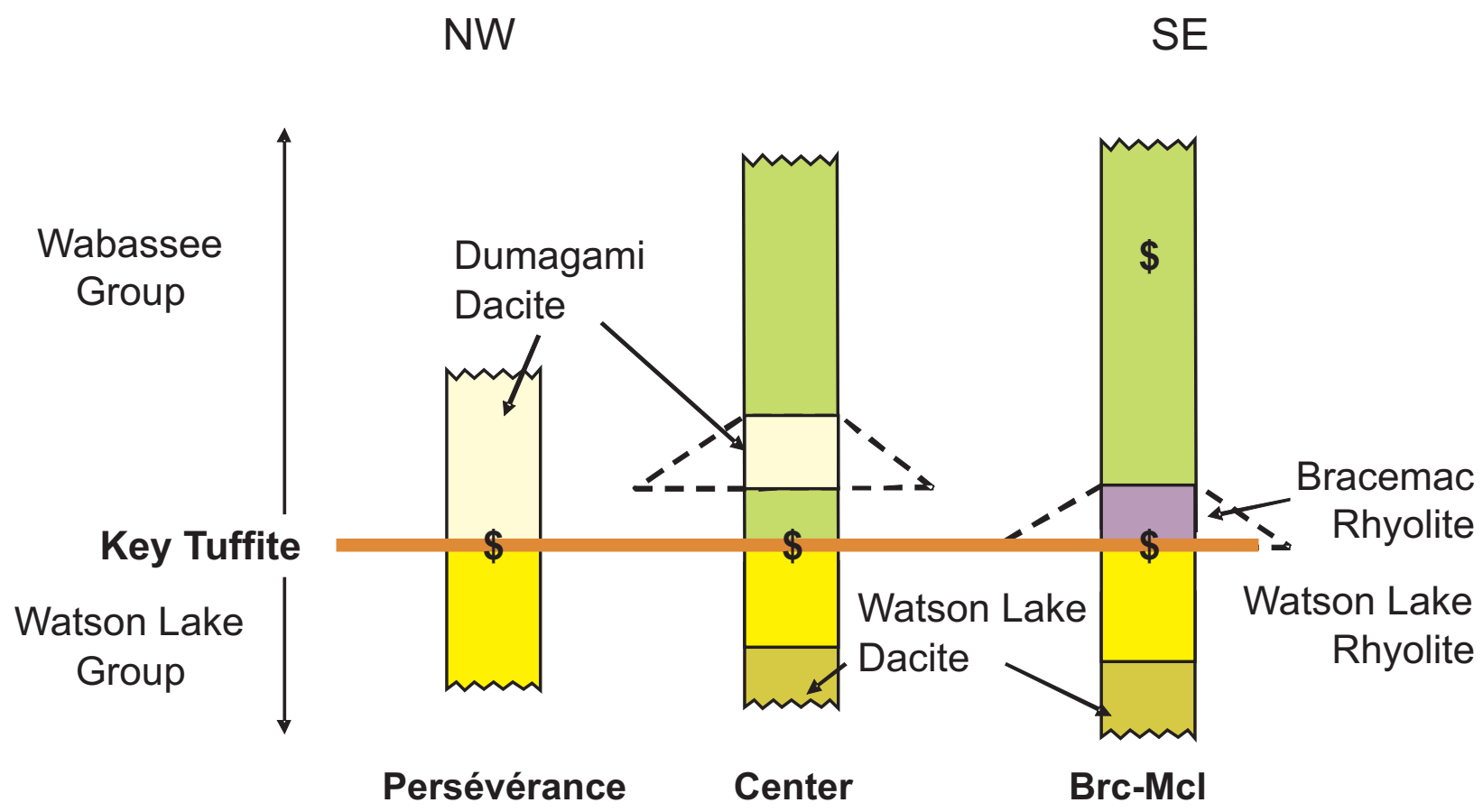

Fresia et al., Fig 02 


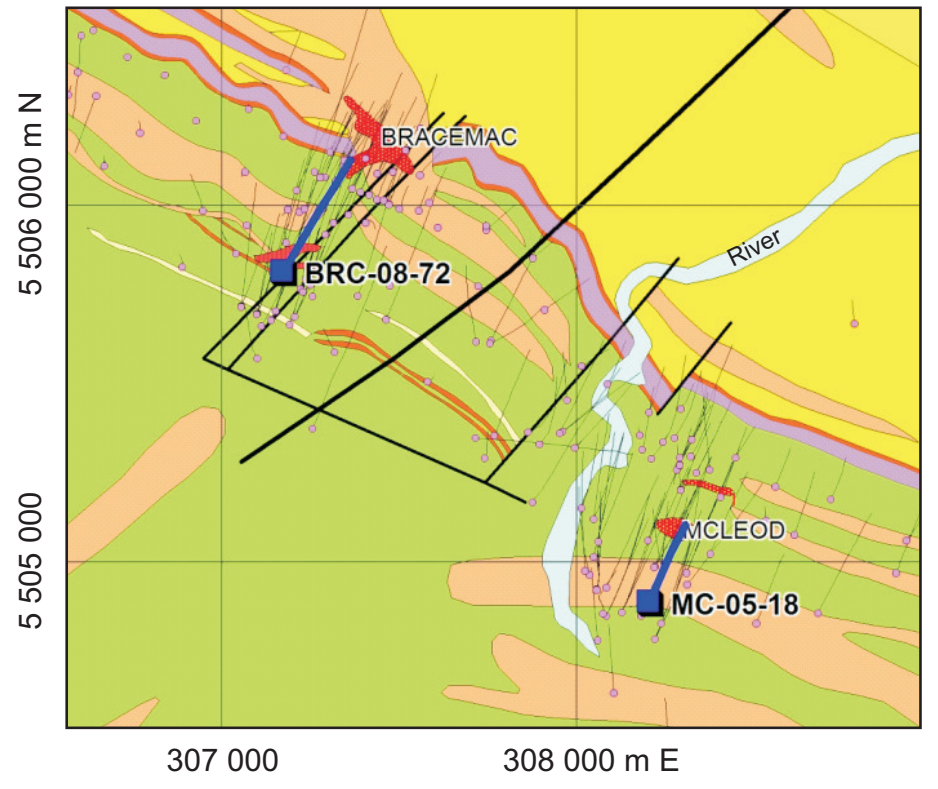

$\longleftarrow$ Drill hole (studied)

- Drill hole (not studied)

- Fault

Gabbro \& diorite

$\square$ Basalt \& andesite

$\square$ Bracemac rhyolite

Massive sulfides

$\square$ Tuffite

$\square$ Watson Lake rhyolite 


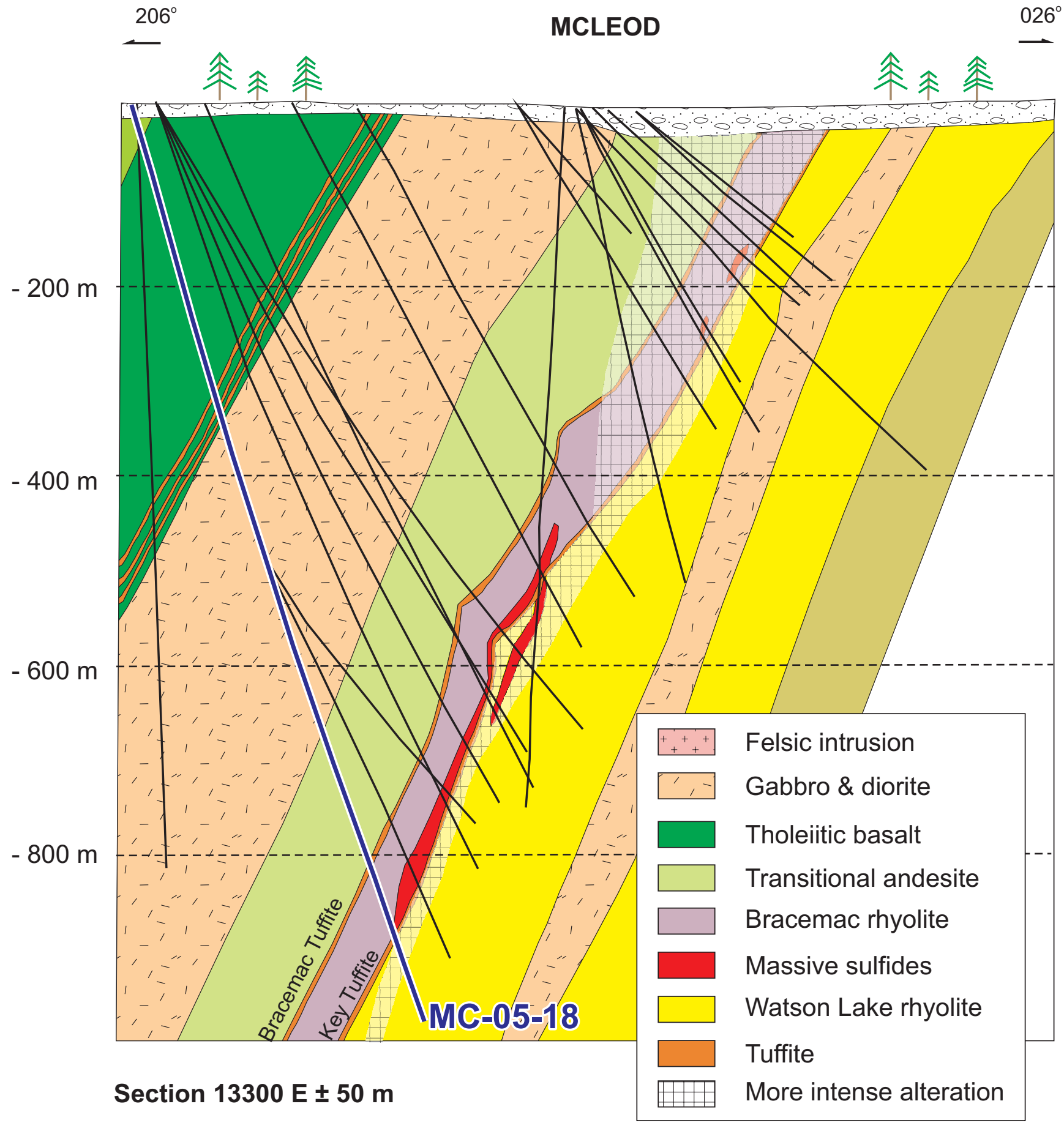




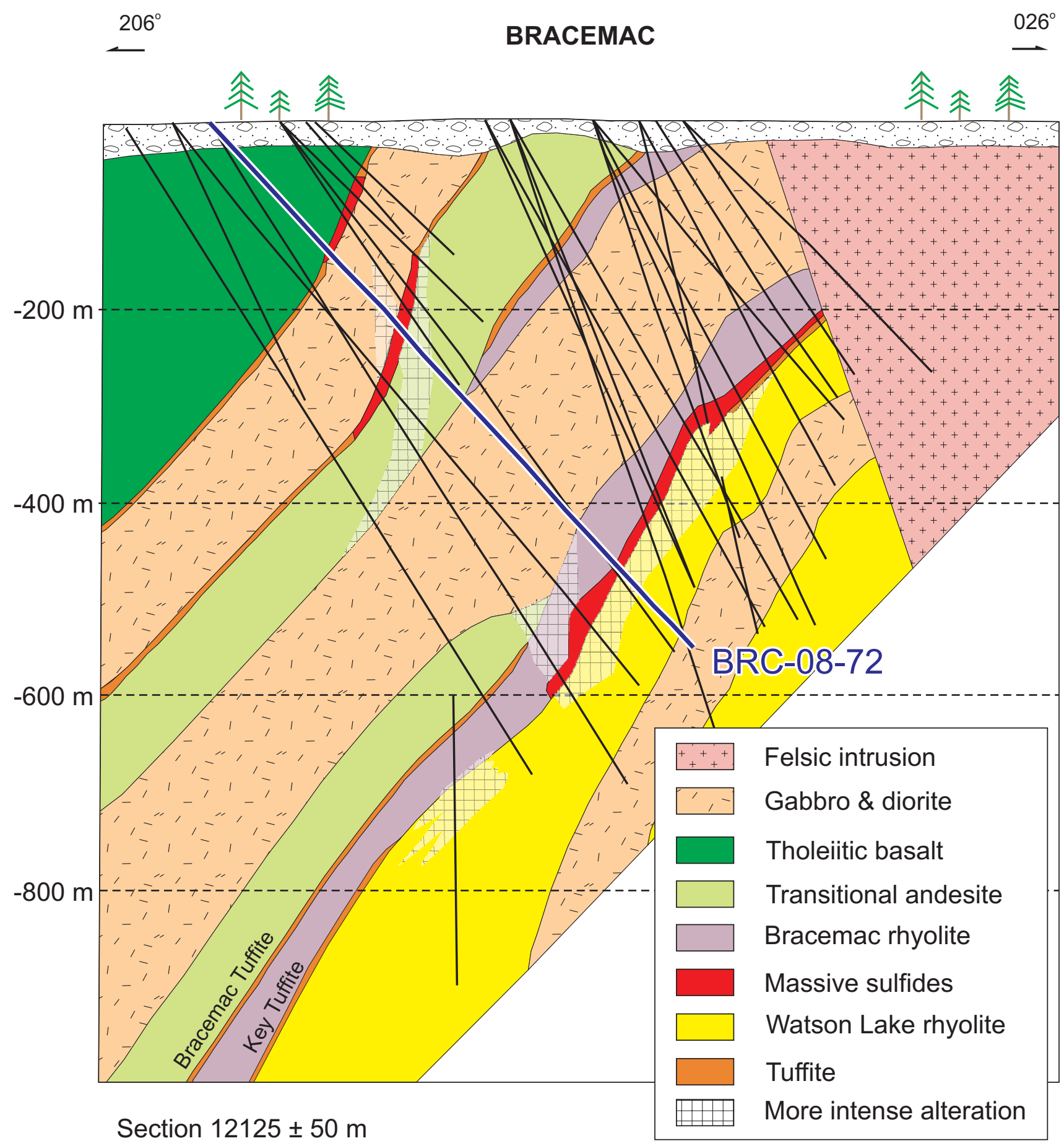

Fresia et al., Fig. 05 
MC-05-18

\section{Company log}

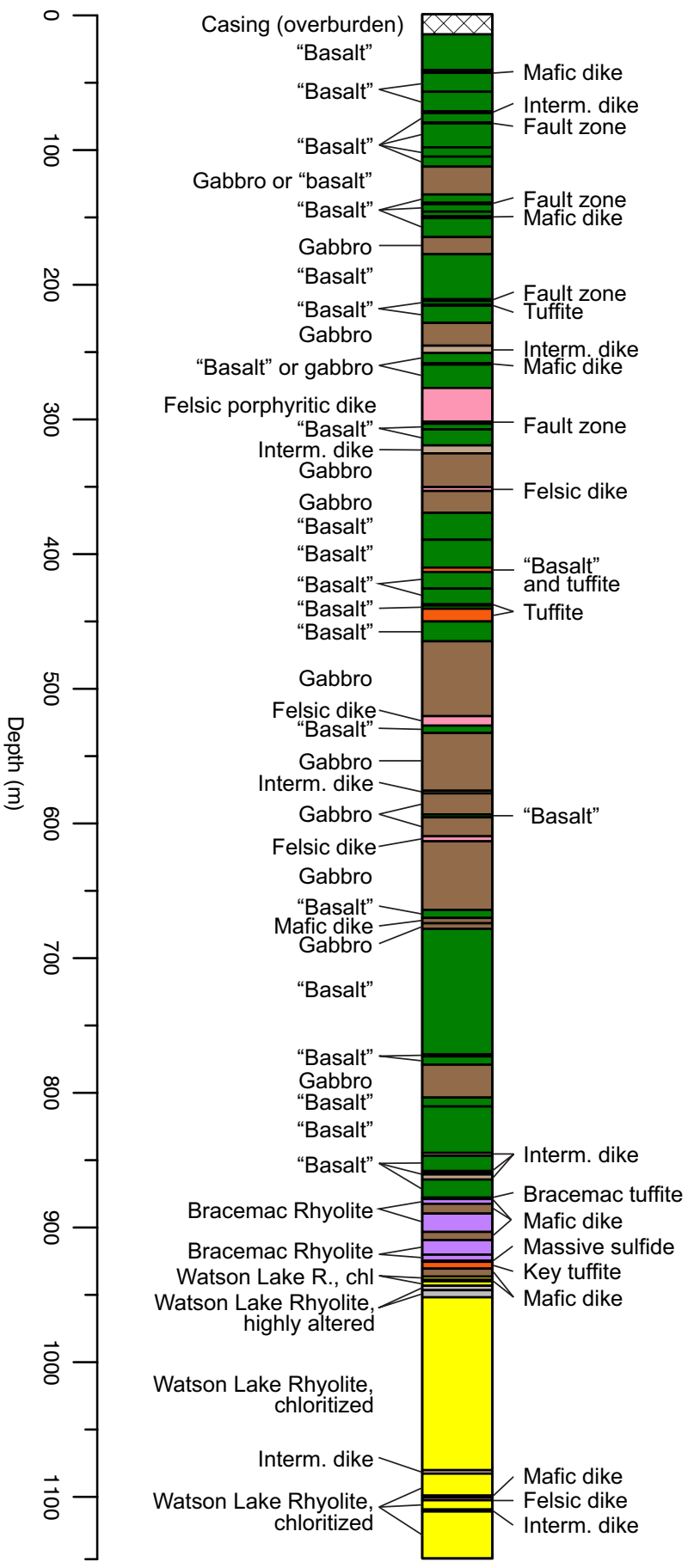

$\begin{array}{llllll}\mathrm{SiO}_{2} & \mathrm{TiO}_{2} & \mathrm{Al}_{2} \mathrm{O}_{3} & \mathrm{Fe}_{2} \mathrm{O}_{3} & \mathrm{MnO} & \mathrm{Zr}\end{array}$
$(\%)$
$(\%)$
$(\%)$
$(\%)$
(\%) (ppm)

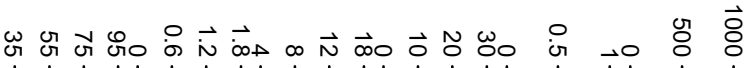

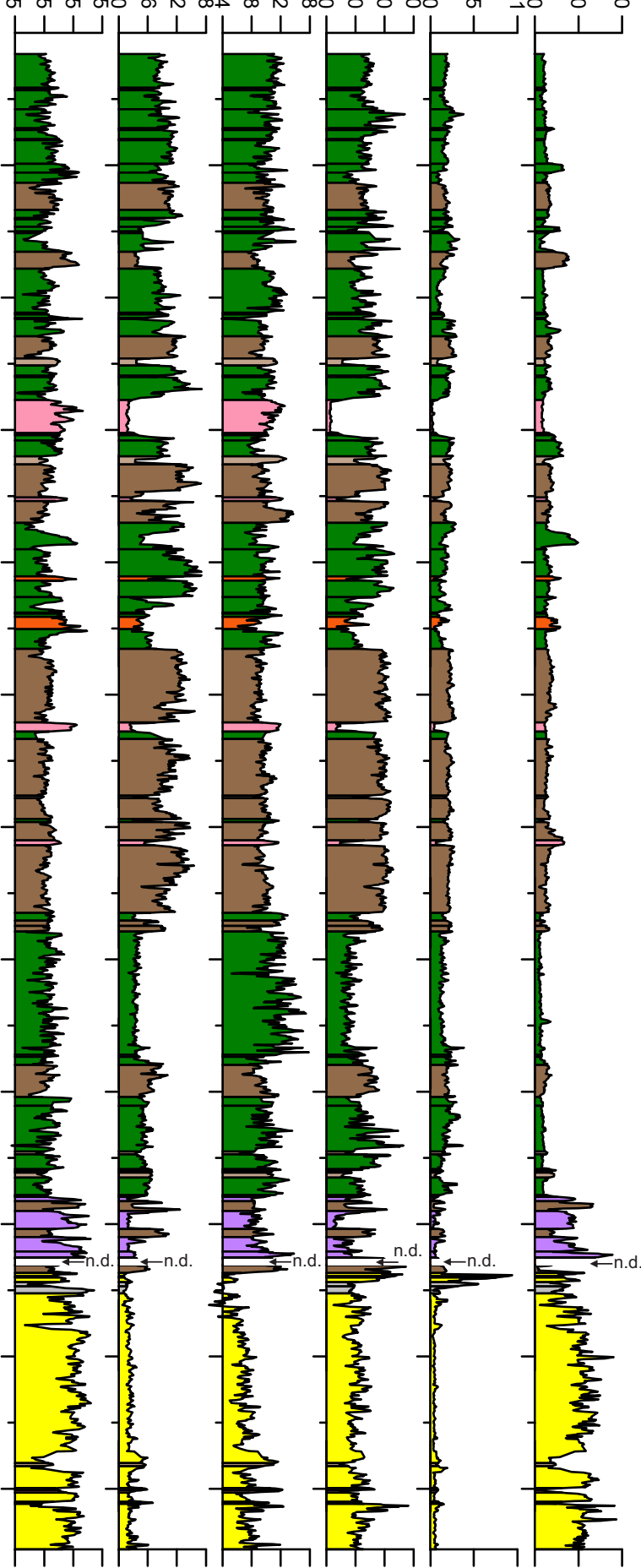


MC-05-18

Company log

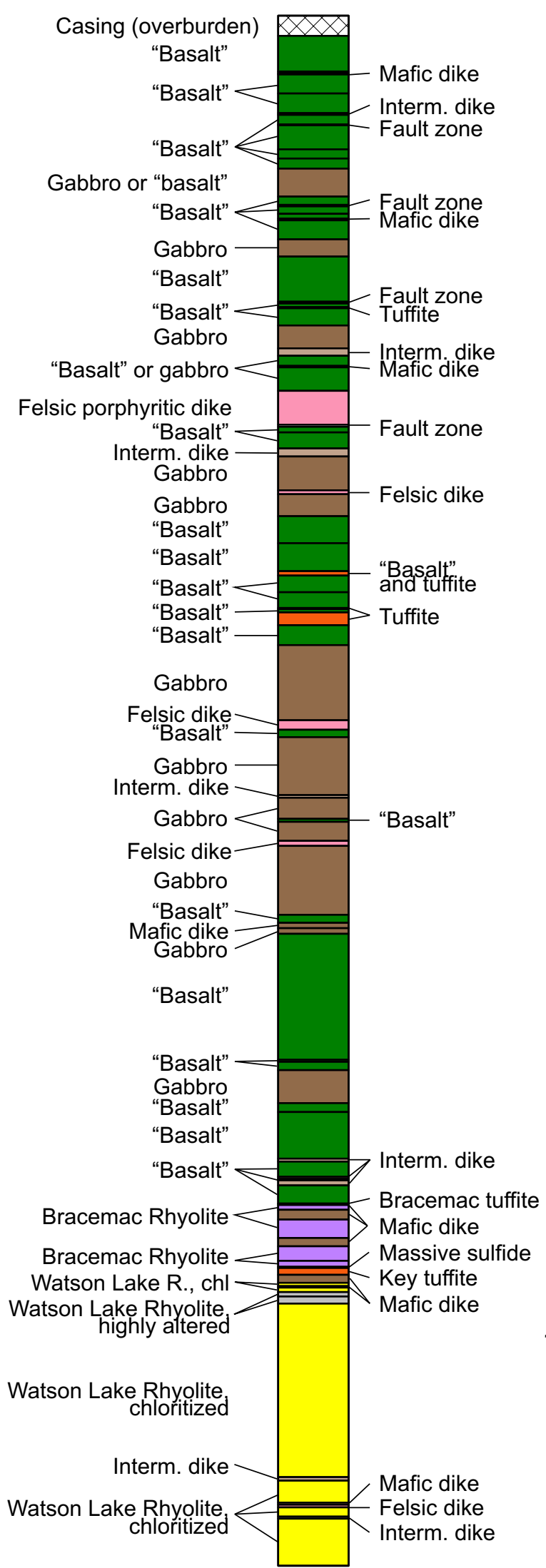

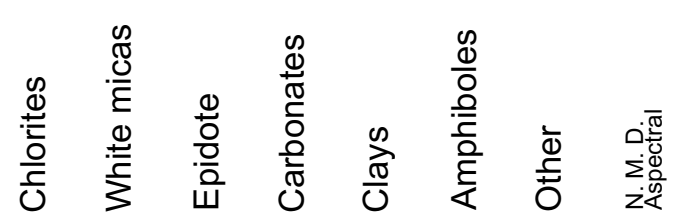
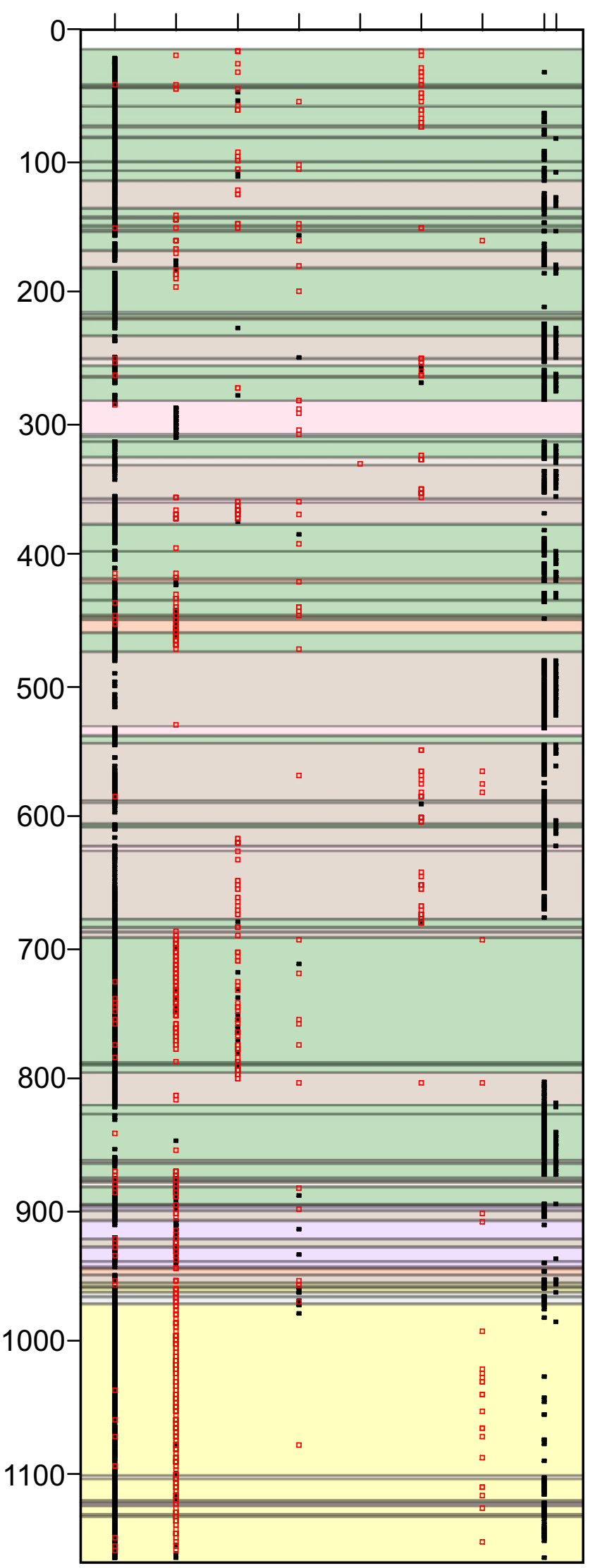

Fresia et al., Fig. 08 


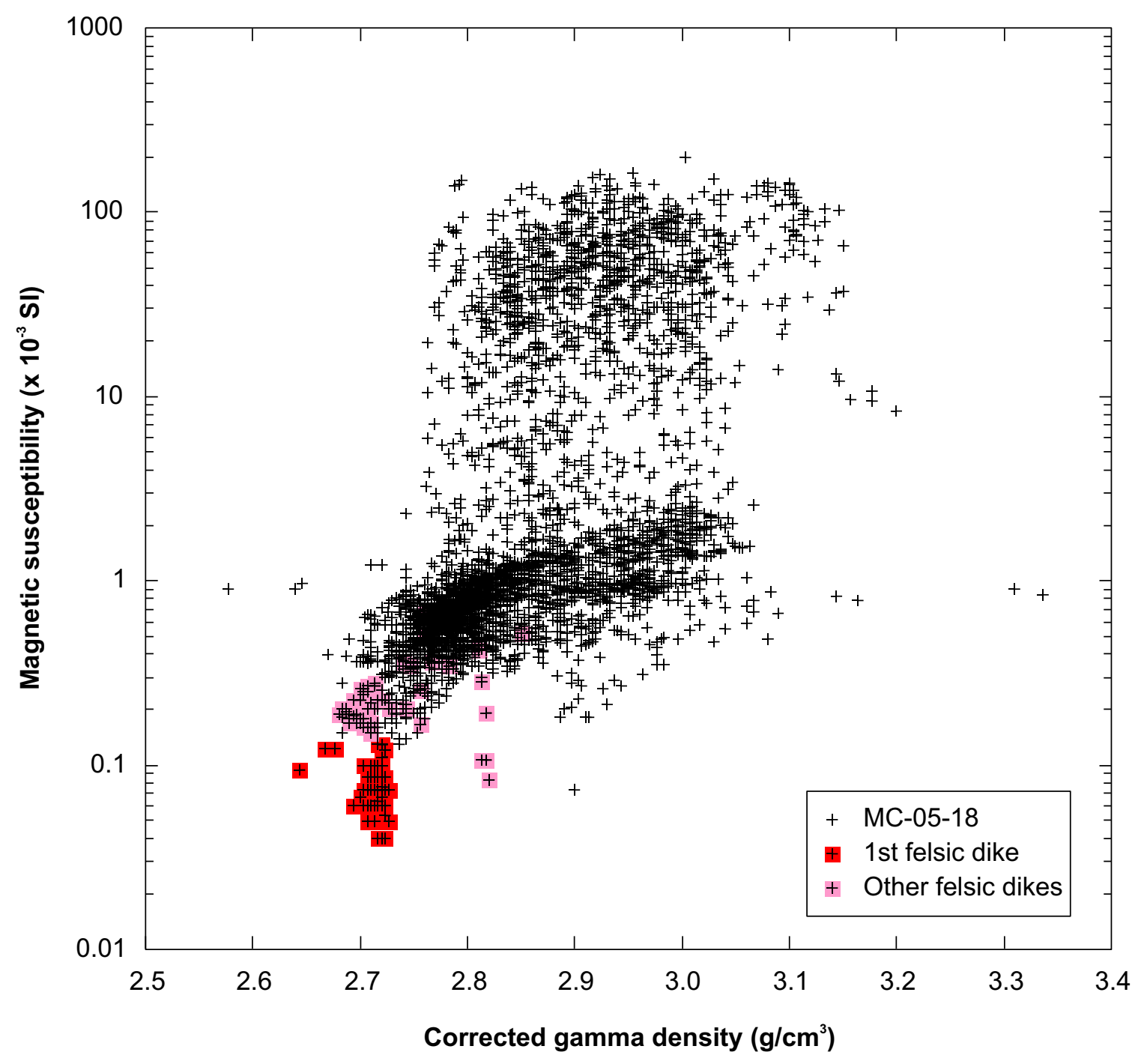

Fresia et al, Fig. 09 


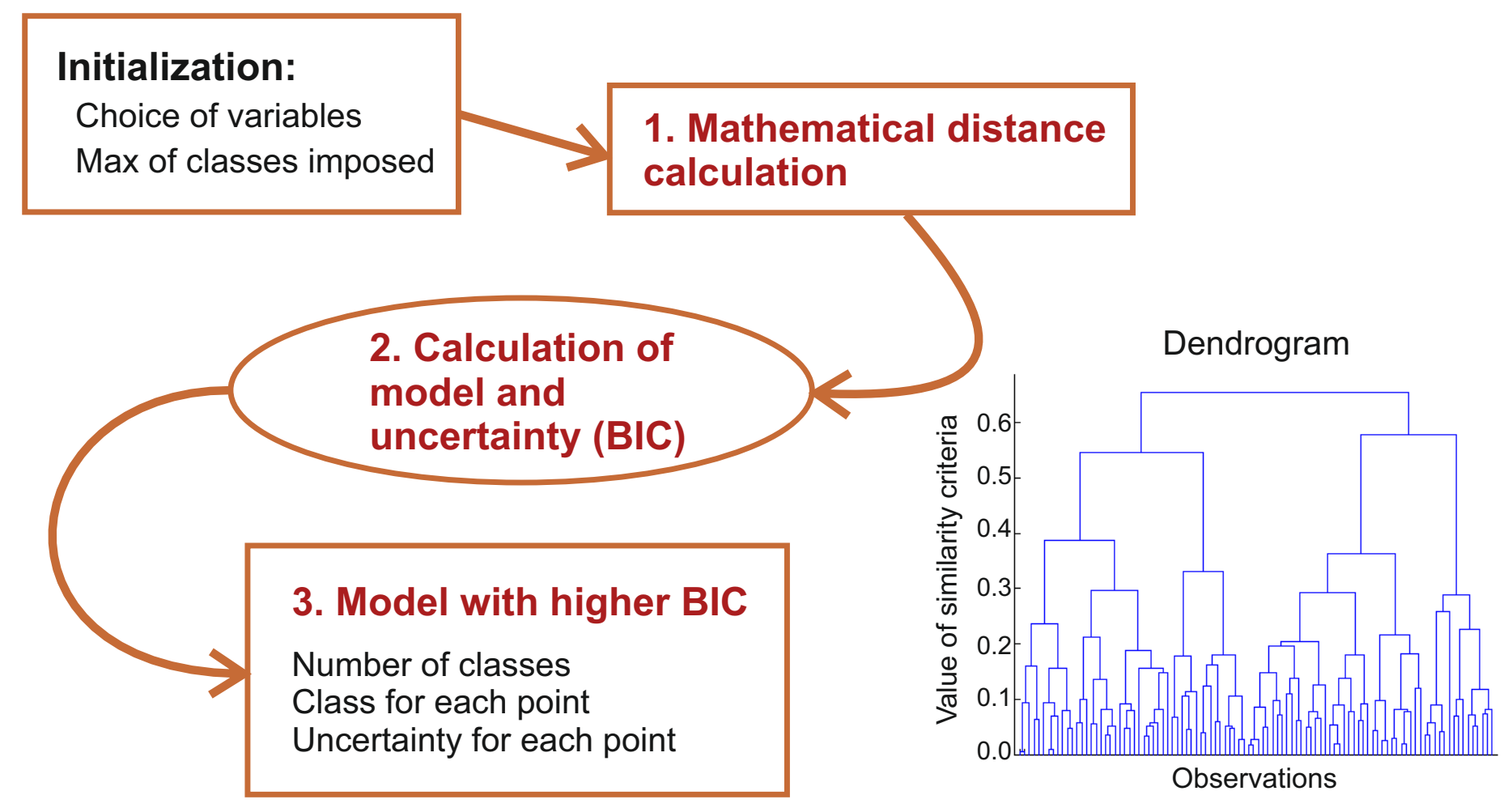




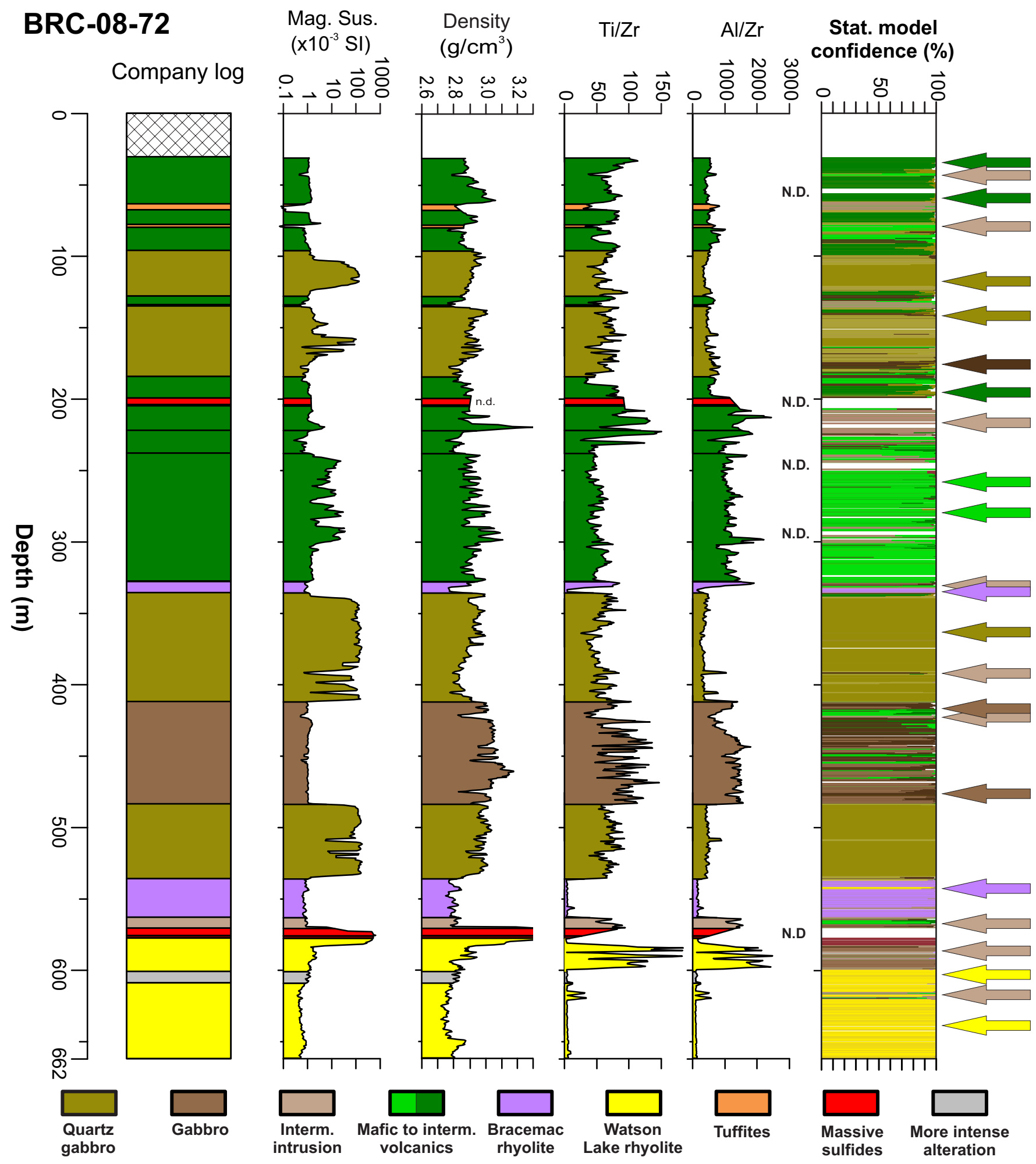

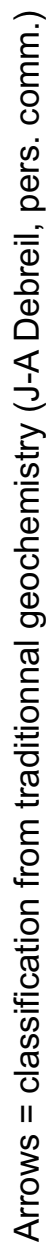




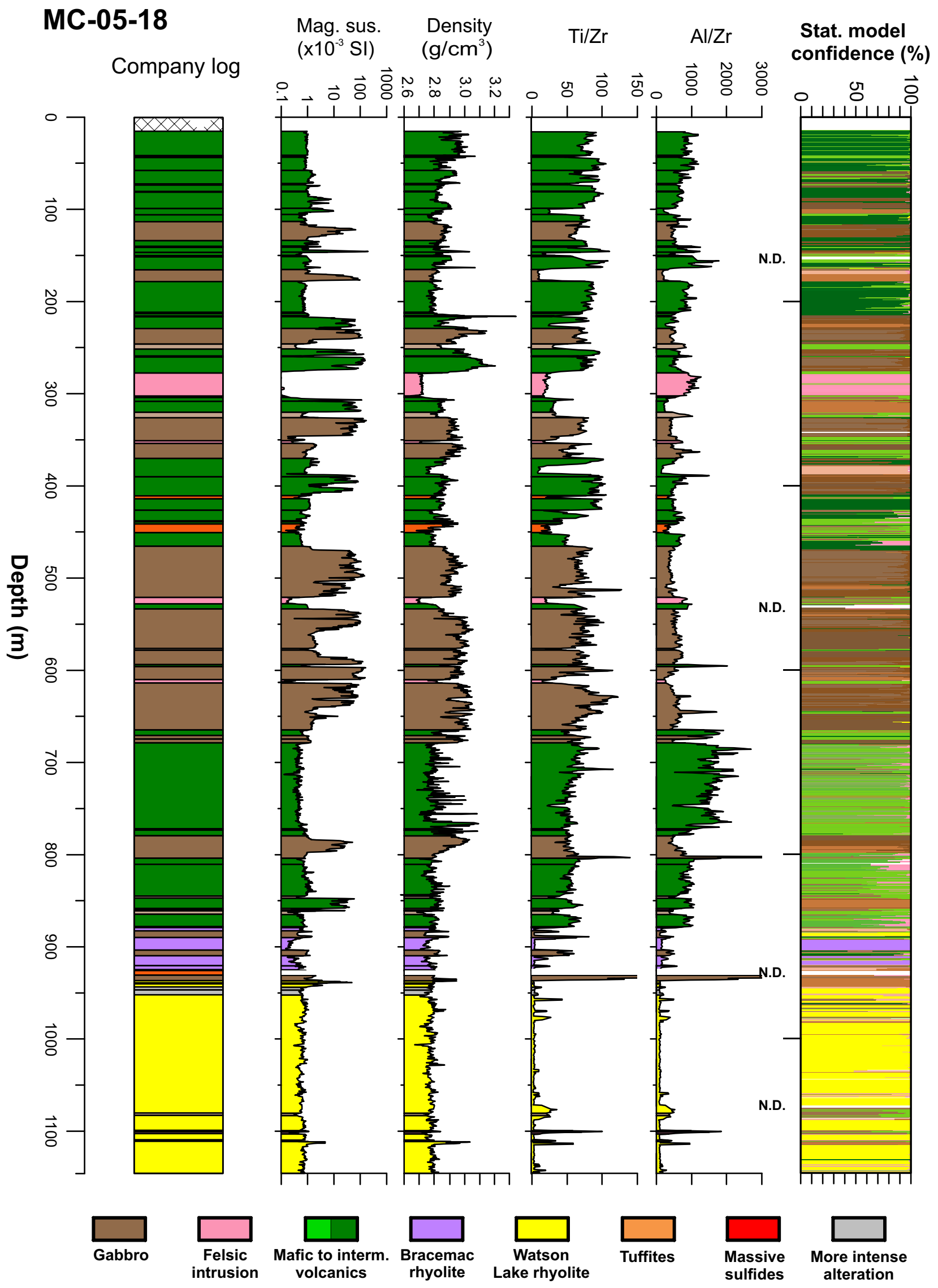

Fresia et al., Fig. 12 